\title{
Effectiveness of Suboccipital Muscle Inhibition Technique versus Muscle Energy Technique on Hamstring Muscle Flexibility in College Going Students
}

\author{
Rooju Vachhani ${ }^{1}$, Himanshi Sharma \\ ${ }^{1}$ Consulting Physiotherapist, Department of Physiotherapy, BAPS Shashtriji Maharaj Multispeciality Hospital, \\ Atladara- Padra, Vadodara (Gujarat) -India \\ ${ }^{2}$ Assistant Professor, Pioneer Physiotherapy College, Ajwa-Nimeta Road near Sayajipura, Vadodara (Gujarat)- \\ India
}

Corresponding Author: Himanshi Sharma

\begin{abstract}
Background:- Hamstring is one of the commonest muscle which often gets tight. Suboccipital muscle inhibition technique is a method of relaxing tension in four muscles located between occiput and axis which regulates the upper cervical vertebra. When the tone of suboccipital muscles falls, it has been reported that the tone of knee flexors such as hamstrings also decreases due to relaxation of myofascia. This is because hamstrings and suboccipital muscles are connected by one neural system, which passes through the duramater called the superficial back line. Muscle energy technique is a procedure that involves voluntary contraction of a patient's muscle in a precisely controlled direction, at varying levels of intensity and has been utilized in lengthening of tight muscles.

Method: The study was done after obtaining approval from ethical committee. Subjects having hamstring tightness who fulfilled inclusion criteria were selected from the population.

52 subjects were included and divided into two groups. The study was carried out for 5 days. Subjects in the experimental group were treated with SMIT and Subjects in control group were treated with MET. Outcome measures used were Active Knee extension test and Back Saver Sit and Reach Test. Data was analysed post treatment (Immediate effects) and at the end of
\end{abstract}

5th session using non- parametric tests at 5\% level of significance.

Result: Within group analysis at post treatment and at the end of $5^{\text {th }}$ session showed significant improvement in both the outcome measures in experimental and control group. Between group analysis showed no significant effect post treatment whereas after 5 days significant difference was found where more improvement was found in the control group i.e. Muscle energy technique group.

Conclusion: Suboccipital Muscle Inhibition Technique and Muscle Energy Technique both were effective in improving hamstring flexibility but Muscle energy technique was found to be more effective.

Keywords: Suboccipital Muscle Inhibition Technique, Muscle Energy Technique (MET), Flexibility, Active Knee Extension (AKE), Back Saver Sit and Reach Test (BSRT).

\section{INTRODUCTION}

Hamstring is one of the commonest muscles of lower limb and is one of the three posterior thigh muscles in between the hip and knee and its action is flexion of knee and extension of hip. ${ }^{1}$

Flexibility is defined as the ability of a muscle to lengthen and allow one joint to move through a range of motion. Limited flexibility predisposes a person to several musculoskeletal overuse injuries and 
significantly affect a person's level of function. ${ }^{2,3}$ Decreased hamstring flexibility is suggested to be one of the predisposing factors for hamstring strains. ${ }^{4,5}$ Hamstring is the commonest muscle which often gets tight and prevalence of hamstring tightness is very high in college going students of age group of $18-25$ years whereas $68 \%$ of peoples are affected. Hence awareness of hamstring stretching is important to prevent musculoskeletal problems of lower quadrant. ${ }^{6}$

Hamstring tightness is not only causative factor for reduced range of motion but it can also be due to various other musculoskeletal problems. ${ }^{7}$ Length tension relationship of the muscle as well as shock absorbing ability of the limb is affected by the tightness of muscle. Modern sedentary lifestyle of living is one of the main reasons for postural abnormalities evident in modern society. The prolonged sitting hours required in most of the jobs, and educational setups can affect the flexibility of soft tissues, especially two joint muscles. ${ }^{8}$ Tight hamstrings can have a profound effect on seated postural alignment of body and number of studies showed positive correlation between decreased hamstring flexibility and low back pain of lumbar intervertebral disc pathology. ${ }^{9}, 10$ Due to attachment of hamstrings to the ischial tuberosity, hamstring tightness generates posterior pelvic tilt and decreases lumbar lordosis which can result in Low Back Pain. ${ }^{11,12}$

There are various treatment for the hamstring stretching like active release technique, ${ }^{13}$ passive stretching, static stretching PNF stretching techniques, ${ }^{14,15}, 16$ eccentric stretching exercises for improving hamstring flexibility. ${ }^{17}$

Suboccipital muscle inhibition technique is a method of relaxing tension in four muscles located between occiput and axis which regulates the upper cervical vertebra (Rectus capitis posterior major, rectus capitis posterior minor, obliques capitis inferior, and obliques capitis superior); these muscles are known to be associated with regulating body posture as well as rotation of head. ${ }^{18,19}$ When the tone of suboccipital muscles falls, it has been reported that the tone of knee flexors such as hamstrings also decreases due to relaxation of myofascia. ${ }^{20}$ This is because hamstrings and suboccipital muscles are connected by one neural system, which passes through the duramater called the superficial back line ${ }^{.21}$

The SMI technique is a method of inducing relaxation of the fascia by applying soft pressure to the suboccipital area of the patient while he/she is lying comfortably and it can be easily applied by the therapist. $^{21}$

Muscle energy technique is a manual technique developed by osteopaths and is now used in many different manual therapy professions. $^{22}$ It is a procedure that involves voluntary contraction of a patient's muscle in a precisely controlled direction, at varying levels of intensity. ${ }^{22}$ Post isometric Relaxation Muscle energy technique has been utilized in lengthening of tight muscles. The term post isometric relaxation refers to subsequent reduction in tone of the agonist after isometric contraction. This occurs due to stretch receptors called Golgi tendon organs that are located in tendon of agonist muscle. ${ }^{23}$ It is claimed to be effective for a variety of purposes including lengthening a shortened muscles, as a lymphatic or venous pump to aid the drainage of fluid or blood and increasing the range of motion. ${ }^{22,} 24$ The neurological mechanisms that may produce increased Range of Motion of the joint after MET, however there is a little research to substantiate these theories. ${ }^{25}$ The effectiveness of MET to the inhibitory golgi tendon reflex. This reflex is believed to be activated during isometric contraction of muscles, which is claimed to produce a stretch on golgi tendon organs and a reflex relaxation of the muscle. ${ }^{26}$

Methods to access hamstring flexibility include the straight-leg raising test, sit and reach test (SR test) and active knee extension test. ${ }^{27,28,29}$ 
The SLR test specificity has been questioned, as it is also widely used as a neurological test. ${ }^{30}$ Further studies showed that pelvic rotation may influence the validity of SLR angle measurements. ${ }^{31}$ Even though the hamstring flexibility assessment is easy using the sit and reach test, the validity of this test is considered poor. ${ }^{32}$ The AKE test is an active test that involves movement at knee joint, and most considers it safe, as the patient dictates the end point of movement. ${ }^{33}$ The assessment of back saver sit and reach test is conceptually similar to sit and reach test, but only one leg is extended against the sit and reach box while the other leg is flexed. The BS appears to be similar to the SR in that it is primarily a test of hamstring extensibility ${ }^{34}$ but the BS test is intended to be safer on the spine by restricting the intervertebral flexion, and can also be used to determine symmetry in hamstring flexibility. ${ }^{35}$ Some studies recommended BS was reported to be more comfortable than the SR in young females. $^{27}$

The Active knee extension test and Back saver sit and reach test is the flexibility test used in this study and the reliability of both the tests are quiet high i.e. the inter-rater reliability intra-class correlation coefficient(ICC) were 0.87 for dominant knee and 0.81 for non dominant knee. $^{36,} 37$ In addition the test-retest reliability was with ICC values ranging from 0.78-0.97 respectively ${ }^{38}$ whereas BSSRT is having reliability of $\mathrm{R}=0.97$ (95\% CI $=0.93-0.98$ ) for men and $\mathrm{R}=0.96$ $(95 \% \mathrm{CI}=0.95-0.98)$ for women. ${ }^{39}$

\section{NEED OF THE STUDY:}

Studies have proved that both Suboccipital muscle inhibition technique ${ }^{20}$ and Muscle energy technique ${ }^{2,22}$ are used for the individuals having hamstring tightness.

But, there is lack of evidence which conducted to compare the effectiveness of Suboccipital muscle inhibition technique versus Muscle energy technique in hamstring tightness individuals for improving flexibility and range of motion.

Study design: Experimental Study

$\square$ Sample design: Convenient Sampling Method

$\square$ Study population: Students having hamstring tightness

Sample size: The main outcome variable for this study was Active Knee Extension (AKE) Test based on the study conducted by Pramod K. Jagtap ${ }^{55}$ and another study conducted by Mohd. Waseem $^{60}$, the mean and SD were taken for calculation from the mother studies.

Keeping $\alpha=0.05$ and power of $80 \%(\beta=0.2)$ the effect size was calculated 0.8 (Based on previous studies) Sample size was calculated by using $\mathrm{G}^{*}$ Power software version 3.1.9.2. The calculated sample size came out to be 52 (26 in each group)

The participants were divided into two groups, i.e. group A and group B,

Group A received (Suboccipital Muscle Inhibition Technique whereas Group B received (Muscle Energy Technique)

Sample setting: Different colleges of Vadodara

Study Duration: 5 days(1 session per day)

Study Period: 1 Year

Ethics Approval: Ethics Approval was obtained for the study by Institutional Review Board (IRB) with proposal number: PPC/OW/1184-F/2019

\section{INCLUSION CRITERIA:}

1) Normal Healthy Individuals with Active knee Extension (popliteal angle) $<125^{\circ}$

2) Both the Genders i.e. males and females.

3) Age group between 18-26 years with hamstring tightness.

4) Individuals with normal BMI i.e. 18.524.9 (WHO)

5) Those who were willing to participate.

\section{EXCLUSION CRITERIA:}

1) Individuals with neck pain, neck trauma (Whiplash injury).

2) Visual Swelling in the region of hamstring Muscle. 
3) Persons were already involved in any exercise programs for lower extremity.

4) Subjects who recently completed an active warm up or participated in sporting activities earlier that day or athletes.

5) Individuals with herniated disc, lumbar protrusion, low back pain and showing neurological symptoms.

6) Individuals with recent fracture of lower limb.

7) Individuals with cervical ligament instability or Migraine.

8) Individuals with vertebra basilar artery syndrome.

9) Inability to understand the informed consent form.

\section{PROCEDURE: -}

After obtaining approval from Institutional Ethical Committee this study was started. Subjects who were fulfilling inclusion criteria were selected from the population. Subjects were explained about the research and treatment protocol. Written consent was obtained from all the subjects before starting the treatment. The participants were randomly divided into two groups:

GROUP A: Subjects were treated with suboccipital muscle inhibition technique $(\mathrm{N}=26)$

GROUP B: Subjects were treated with muscle energy technique $(\mathrm{N}=26)$

Outcome measures were obtained before and after the program schedule.

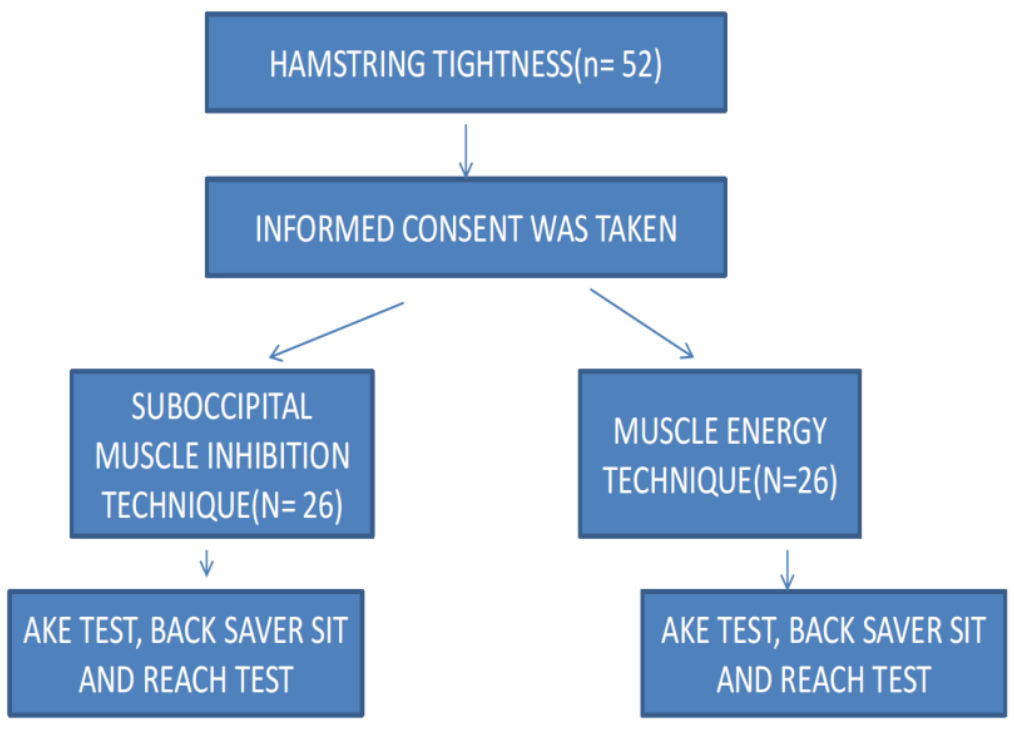

FIGURE: 1: CONSORT DIAGRAM

\section{GROUP A: Suboccipital muscle inhibition technique: ${ }^{55}$}

Position of the patient was supine, the therapist was sitting at the head of the table and placed the palms of hand under the subjects head, pads of therapist's fingers were on the projection of the posterior arch of the atlas which was palpated between the external occipital protuberance and spinous process of axis of vertebra. The therapist locates with the help of middle and ring fingers of both hands, the space between the occipital condyles and the spinous process of second cervical vertebra. Then with the metacarpophalangeal joints in 90 degree flexion, therapist rests the base of skull on hands. Pressure was exerted upward and toward the therapist. The pressure was maintained for 2 minutes until tissue relaxation was achieved. During the SMI technique, the subject was asked to keep his/her eyes closed to avoid eye movements affecting the suboccipital muscle tone. ${ }^{20}$ The treatment was continued for 5 consecutive days and post treatment( Immediate effect) and at the end of $5^{\text {th }}$ session post treatment assessment was done with active knee 
extension test and back saver sit and reach test. $^{55}$

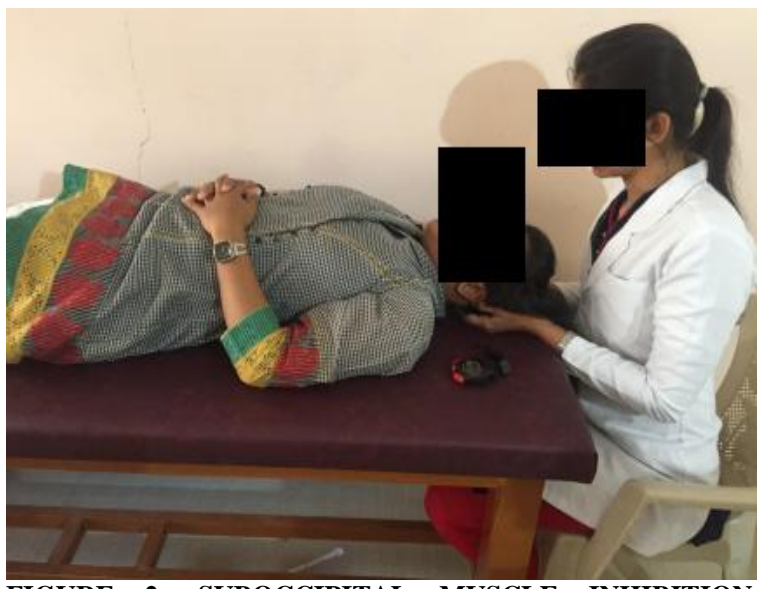

FIGURE 2: SUBOCCIPITAL MUSCLE INHIBITION TECHNIQUE

\section{GROUP B: Muscle energy Technique: -}

Muscle energy technique was applied using post isometric relaxation technique. While the subject was lying in supine position, the subject's hip was passively flexed by the therapist until the bend was felt. From this position, the subject's lower leg was placed onto the therapist's right shoulder. Then the subject was asked to apply the pressure over the shoulder of the therapist for 7-10 seconds followed by 2-3 seconds of relaxation. After the contraction of the hamstrings and during the relaxation phase, the therapist passively took the leg into further flexion with 30 seconds hold. Then the subject's leg was lowered on to the treatment table for the short resting time. This procedure was repeated two more times. ${ }^{54,22}$

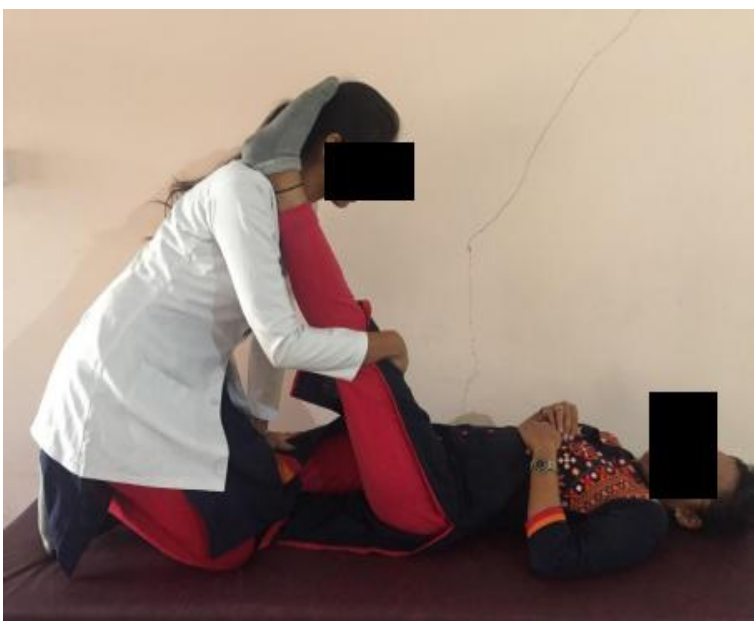

FIGURE 3: MUSCLE ENERGY TECHNIQUE

\section{STATISTICAL ANALYSIS: -}

Data was analysed by SPSS software version 20.0 and Microsoft Excel 2010. Prior to the statistical test data was screened for normal distribution. According to Normal Distribution tests were applied for within group and between group analysis.

In this study Effectiveness of Suboccipital Muscle Inhibition Technique versus Muscle energy technique on Hamstring Flexibility were examined. Hamstring Flexibility was assessed by Active Knee Extension test (AKE) And Back Saver Sit and Reach test. 52 participants were recruited in this study, 26 in each group. Group A was treated with Suboccipital Muscle Inhibition Technique and Group B was treated by Muscle Energy Technique.

Given below (Table 1) illustrates the descriptive characteristics of all the variables.

TABLE :1- BASELINE DATA

\begin{tabular}{|l|l|l|l|}
\hline CATEGORIES & $\begin{array}{l}\text { SUBOCCIPITAL MUSCLE INHIBITION } \\
\text { TECHNIQUE }\end{array}$ & $\begin{array}{l}\text { MUSCLE ENERGY } \\
\text { TECHNIQUE }\end{array}$ & VALUE \\
\hline NO OF SUBJECTS & 26 & 26 & \\
\hline & MEAN \pm SD & MEAN \pm SD & 0.100 \\
\hline AGE & $21.73 \pm 1.77$ & $22.46 \pm 1.67$ & 0.431 \\
\hline BMI & $21.25 \pm 1.78$ & $21.73 \pm 2.22$ & \\
\hline GENDER & FEMALE: 22 & FEMALE: 16 & MALE: 10 \\
\hline & MALE: 4 & \multicolumn{2}{c}{} \\
\hline
\end{tabular}

\section{DATA ANALYSIS:}

Total 52 subjects were recruited in this study, 26 in each group. Data was entered in Microsoft Excel 2010 and analysis was done using SPSS software version 20.0. Descriptive statistics were calculated in form of mean age and BMI. Data was not normally distributed for all the outcome measures So, Non- parametric tests were applied for within group and between group analysis. Data was analysed at 5\% level of significance with confidence 
Rooju Vachhani et.al. Effectiveness of suboccipital muscle inhibition technique versus muscle energy technique on hamstring muscle flexibility in college going students.

interval (CI) at 95\%. Within group analysis was done by Wilcoxon Signed Rank Test and between groups analysis was done by Mann- Whitney U Test.
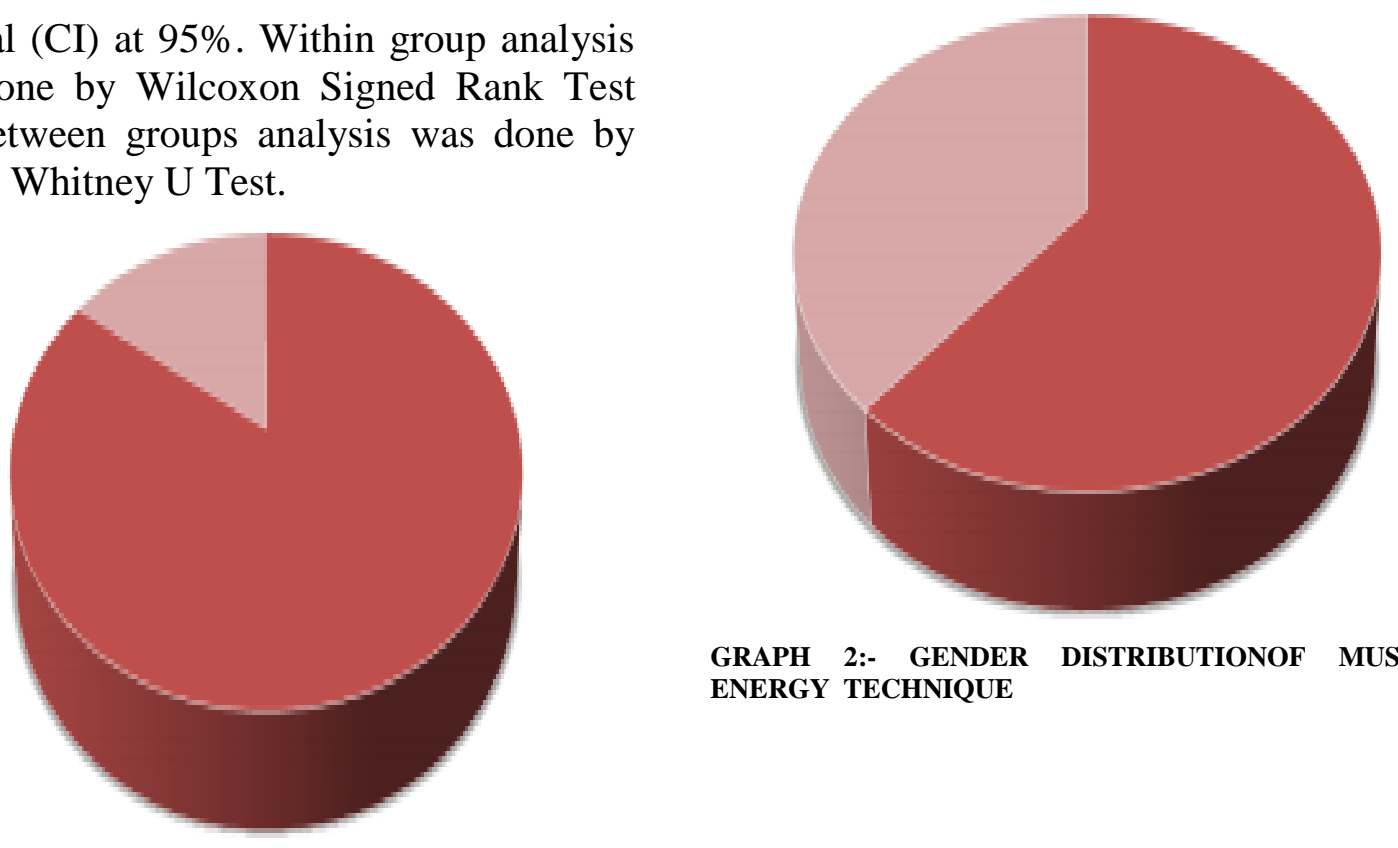

GRAPH 2:- GENDER DISTRIBUTIONOF MUSCLE ENERGY TECHNIQUE

GRAPH1: GENDER DISTRIBUTION OF SUBOCCIPITAL MUSCLE INHIBITION TECHNIQUE

TABLE :2 : INTRA GROUP COMPARISON OF GROUP A

\begin{tabular}{|c|c|c|c|c|c|c|c|c|c|}
\hline \multirow{3}{*}{ OUTCOME MEASURES } & \multicolumn{4}{|c|}{ GROUP A } & \multirow{2}{*}{\multicolumn{2}{|c|}{$\begin{array}{l}\text { W } \\
\text { VALUE }\end{array}$}} & \multirow{2}{*}{\multicolumn{2}{|c|}{ P VALUE }} & \multirow{3}{*}{ REMARKS } \\
\hline & \multicolumn{2}{|c|}{$\begin{array}{l}\text { PRE TEST } \\
(\text { MEAN } \\
\pm \text { SD) } \\
\end{array}$} & \multicolumn{2}{|c|}{$\begin{array}{l}\text { POST TEST } \\
\text { (IMMEDIATE } \\
\text { EFFECT) } \\
(\text { MEAN } \pm \text { SD) }\end{array}$} & & & & & \\
\hline & RT LEG & LT LEG & RT LEG & LT LEG & $\begin{array}{l}\text { RT } \\
\text { LEG }\end{array}$ & $\begin{array}{l}\text { LT } \\
\text { LEG }\end{array}$ & $\begin{array}{l}\text { RT } \\
\text { LEG }\end{array}$ & $\begin{array}{l}\text { LT } \\
\text { LEG }\end{array}$ & \\
\hline AKE TEST & $\begin{array}{l}119.9 \\
\pm 2.8\end{array}$ & $\begin{array}{l}120.5 \\
\pm 2.8\end{array}$ & $\begin{array}{l}125.0 \\
\pm 3.0\end{array}$ & $\begin{array}{l}125.8 \\
\pm 2.8\end{array}$ & -4.5 & -4.6 & 0.001 & 0.001 & SIGNIFICANT \\
\hline BSSRT & $\begin{array}{l}12.1 \\
\pm 4.7\end{array}$ & $\begin{array}{l}12.7 \\
\pm 5.1\end{array}$ & $\begin{array}{l}15.7 \\
\pm 5.0\end{array}$ & $\begin{array}{l}16.3 \\
\pm 5.2\end{array}$ & -4.4 & -4.4 & 0.001 & 0.001 & SIGNIFICANT \\
\hline
\end{tabular}

Wilcoxon's rank test was used for within group comparison for pre test and post test (Immediate effects) as shown in table 2. For Group A there was a significant improvement in flexibility and this difference was statistically significant $(\mathrm{p}<0.05)$. This improvement in all the outcome measures was clearly seen in the Graph 3.

\begin{tabular}{|c|c|c|c|c|c|c|c|c|c|}
\hline \multirow[t]{3}{*}{ OUTCOME MEASURES } & \multicolumn{4}{|c|}{ GROUP A } & \multirow{2}{*}{\multicolumn{2}{|c|}{$\begin{array}{l}\text { W } \\
\text { VALUE }\end{array}$}} & \multirow{2}{*}{\multicolumn{2}{|c|}{ P VALUE }} & \multirow{3}{*}{$\begin{array}{l}\text { REMAR } \\
\text { KS }\end{array}$} \\
\hline & \multicolumn{2}{|c|}{$\begin{array}{l}\text { POST TEST } \\
\text { (IMMEDIATE } \\
\text { EFFECT) }(\text { MEAN } \pm \text { SD) }\end{array}$} & \multicolumn{2}{|c|}{$\begin{array}{l}5^{\mathrm{TH} D A Y} \\
(\mathrm{MEAN} \pm \mathrm{SD})\end{array}$} & & & & & \\
\hline & RT LEG & LT LEG & RT LEG & LT LEG & $\begin{array}{l}\text { RT } \\
\text { LEG }\end{array}$ & $\begin{array}{l}\text { LT } \\
\text { LEG }\end{array}$ & $\begin{array}{l}\text { RT } \\
\text { LEG }\end{array}$ & $\begin{array}{l}\text { LT } \\
\text { LEG }\end{array}$ & \\
\hline AKE TEST & $125.0 \pm 3.0$ & $125.8 \pm 2.8$ & $129.3 \pm 3.4$ & $130.3 \pm 3.2$ & -4.6 & -4.7 & 0.001 & 0.001 & SIGNIFICANT \\
\hline BSSRT & $15.7 \pm 5.0$ & $16.3 \pm 5.21$ & $21.5 \pm 4.5$ & $22.1 \pm 4.7$ & -4.4 & -4.4 & 0.001 & 0.001 & SIGNIFICANT \\
\hline
\end{tabular}

Wilcoxon's rank test was used for within group comparison for post test (Immediate effect) and $5^{\text {th }}$ day as shown in table 3. For Group A there was found improvement in flexibility and this difference was statistically significant $(\mathrm{p}<0.05)$. This improvement in all the outcome measures was clearly seen in Graph 3.

TABLE :4 : INTRA GROUP COMPARISON OF GROUP A

\begin{tabular}{|c|c|c|c|c|c|c|c|c|c|}
\hline \multirow{3}{*}{ OUTCOME MEASURES } & \multicolumn{4}{|c|}{ GROUP A } & \multirow{2}{*}{\multicolumn{2}{|c|}{$\begin{array}{l}\text { W } \\
\text { VALUE }\end{array}$}} & \multirow{2}{*}{\multicolumn{2}{|c|}{ P VALUE }} & \multirow{3}{*}{ REMARKS } \\
\hline & \multicolumn{2}{|c|}{$\begin{array}{l}\text { PRE TEST } \\
(\text { MEAN } \pm \text { SD) }\end{array}$} & \multicolumn{2}{|c|}{$\begin{array}{l}\mathbf{5}^{\mathrm{TH}} \mathrm{DAY} \\
(\mathrm{MEAN} \pm \mathrm{SD})\end{array}$} & & & & & \\
\hline & RT LEG & LT LEG & RT LEG & LT LEG & $\begin{array}{l}\text { RT } \\
\text { LEG }\end{array}$ & $\begin{array}{l}\text { LT } \\
\text { LEG }\end{array}$ & $\begin{array}{l}\text { RT } \\
\text { LEG }\end{array}$ & $\begin{array}{l}\text { LT } \\
\text { LEG }\end{array}$ & \\
\hline AKE TEST & $119.9 \pm 2.8$ & $120.5 \pm 2.8$ & $129.3 \pm 3.4$ & $130.3 \pm 3.2$ & -4.5 & -4.5 & 0.001 & 0.001 & SIGNIFICANT \\
\hline BSSRT & $12.1 \pm 4.7$ & $12.7 \pm 5.1$ & $21.5 \pm 4.5$ & $22.1 \pm 4.7$ & -4.4 & -4.4 & 0.001 & 0.001 & SIGNIFICANT \\
\hline
\end{tabular}




\section{AKE TEST- ACTIVE KNEE EXTENSION TEST BSSRT- BACK SAVER SIT AND REACH TEST}

Wilcoxon's rank test was used for within group comparison for pre-test and at the end of $5^{\text {th }}$ day shown in table 4 . For Group A there was found improvement in flexibility and this difference was statistically significant $(\mathrm{p}<0.05)$. This improvement in all the outcome measures were clearly seen in Graph 3.

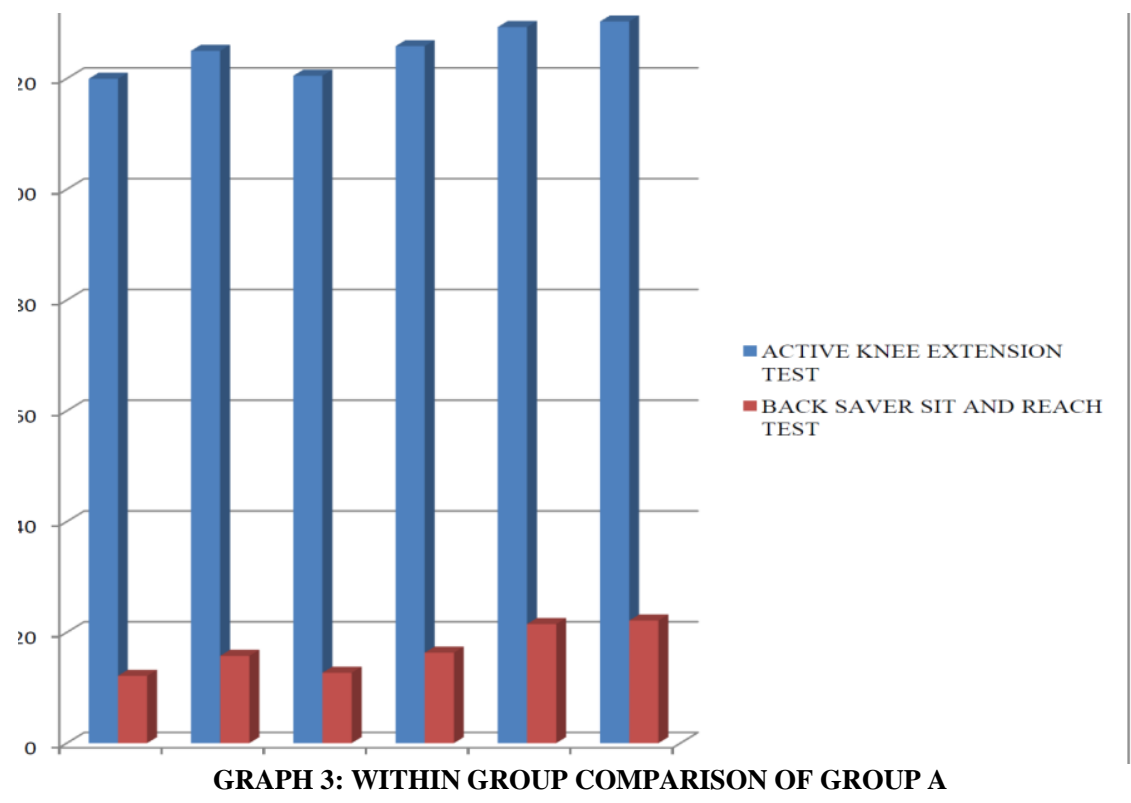

\begin{tabular}{|c|c|c|c|c|c|c|c|c|c|}
\hline \multirow[t]{3}{*}{ OUTCOME MEASURES } & \multicolumn{4}{|l|}{ GROUP B } & \multirow{2}{*}{\multicolumn{2}{|c|}{$\begin{array}{l}\text { W } \\
\text { VALUE }\end{array}$}} & \multirow{2}{*}{\multicolumn{2}{|c|}{ P VALUE }} & \multirow[t]{3}{*}{ REMARKS } \\
\hline & \multicolumn{2}{|c|}{$\begin{array}{l}\text { PRE TEST } \\
(\mathrm{MEAN} \pm \text { SD) }\end{array}$} & \multicolumn{2}{|c|}{$\begin{array}{l}\text { POST TEST } \\
(\text { IMMEDIATE } \\
\text { EFFECT) }(\text { MEAN } \pm \text { SD })\end{array}$} & & & & & \\
\hline & RT LEG & LT LEG & RT LEG & LT LEG & $\begin{array}{l}\text { RT } \\
\text { LEG }\end{array}$ & $\begin{array}{l}\text { LT } \\
\text { LEG }\end{array}$ & $\begin{array}{l}\text { RT } \\
\text { LEG }\end{array}$ & $\begin{array}{l}\text { LT } \\
\text { LEG }\end{array}$ & \\
\hline AKE TEST & $119.8 \pm 3.3$ & $120.3 \pm 3.1$ & $124.8 \pm 3.1$ & $124.9 \pm 3.17$ & -4.6 & -4.68 & 0.001 & 0.001 & SIGNIFICANT \\
\hline BSSRT & $11.9 \pm 4.0$ & $12.2 \pm 3.9$ & $15.7 \pm 4.3$ & $16.0 \pm 4.33$ & -4.5 & -4.50 & 0.001 & 0.001 & SIGNIFICANT \\
\hline
\end{tabular}

Wilcoxon's rank test was used for within group comparison for pre test and post test (Immediate effect) as shown in table 5. For Group B there was found improvement in flexibility and this difference was statistically significant $(\mathrm{p}<0.05)$. This improvement in all the outcome measures was clearly seen in the Graph 4.

TABLE :6 : INTRA GROUP COMPARISON OF GROUP B

\begin{tabular}{|c|c|c|c|c|c|c|c|c|c|}
\hline \multirow[t]{3}{*}{ OUTCOME MEASURES } & \multicolumn{4}{|c|}{ GROUP B } & \multirow{2}{*}{\multicolumn{2}{|c|}{$\begin{array}{l}\text { W } \\
\text { VALUE }\end{array}$}} & \multirow{2}{*}{\multicolumn{2}{|c|}{ P VALUE }} & \multirow{3}{*}{ REMARKS } \\
\hline & \multicolumn{2}{|c|}{$\begin{array}{l}\text { POST TEST } \\
\text { (IMMEDIATE } \\
\text { EFFECT) } \\
(\text { MEAN } \pm \text { SD) }\end{array}$} & \multicolumn{2}{|c|}{$\begin{array}{l}5^{\mathrm{TH}} \text { DAY } \\
(\mathrm{MEAN} \pm \text { SD) }\end{array}$} & & & & & \\
\hline & RT LEG & LT LEG & RT LEG & LT LEG & $\begin{array}{l}\text { RT } \\
\text { LEG }\end{array}$ & $\begin{array}{l}\text { LT } \\
\text { LEG }\end{array}$ & $\begin{array}{l}\text { RT } \\
\text { LEG }\end{array}$ & $\begin{array}{l}\text { LT } \\
\text { LEG }\end{array}$ & \\
\hline AKE TEST & $124.8 \pm 3.1$ & $124.9 \pm 3.1$ & $132.5 \pm 3.8$ & $132.9 \pm 3.90$ & -4.5 & -4.60 & 0.001 & 0.001 & SIGNIFICANT \\
\hline BSSRT & $15.7 \pm 4.31$ & $16.0 \pm 4.33$ & $22.8 \pm 4.61$ & $23.0 \pm 4.26$ & -4.4 & -4.47 & 0.001 & 0.001 & SIGNIFICANT \\
\hline
\end{tabular}

Wilcoxon's rank test was used for within group comparison for post test (Immediate effect) and $5^{\text {th }}$ day as shown in table 6. For Group B there was found improvement in flexibility and this difference was statistically significant $(\mathrm{p}<$
0.05). The improvement in all the outcome measures is clearly seen in Graph 4.

\section{AKE TEST- ACTIVE KNEE EXTENSION TEST BSSRT- BACK SAVER SIT AND REACH TEST}

Wilcoxon's rank test was used for within group comparison for pre test and at 
Rooju Vachhani et.al. Effectiveness of suboccipital muscle inhibition technique versus muscle energy technique on hamstring muscle flexibility in college going students.

the end of $5^{\text {th }}$ day shown in table 7 . For Group B there was found improvement in flexibility and this difference was statistically significant $(p<0.05)$. The improvements in all the outcome measures are clearly seen in Graph 4.

TABLE 7 : -INTRA GROUP COMPARISON OF GROUP B

\begin{tabular}{|c|c|c|c|c|c|c|c|c|c|}
\hline \multirow{3}{*}{$\begin{array}{l}\text { OUTCOME } \\
\text { MEASURES }\end{array}$} & \multicolumn{4}{|c|}{ GROUP B } & \multirow{2}{*}{\multicolumn{2}{|c|}{$\begin{array}{l}\text { W } \\
\text { VALUE }\end{array}$}} & \multirow{2}{*}{\multicolumn{2}{|c|}{ P VALUE }} & \multirow[t]{3}{*}{ REMARKS } \\
\hline & \multicolumn{2}{|c|}{ PRE TEST $($ MEAN \pm SD) } & \multicolumn{2}{|c|}{$5^{\mathrm{TH}}$ DAY $($ MEAN \pm SD $)$} & & & & & \\
\hline & RT LEG & LT LEG & RT LEG & LT LEG & $\begin{array}{l}\text { RT } \\
\text { LEG }\end{array}$ & $\begin{array}{l}\text { LT } \\
\text { LEG }\end{array}$ & $\begin{array}{l}\text { RT } \\
\text { LEG }\end{array}$ & $\begin{array}{l}\text { LT } \\
\text { LEG }\end{array}$ & \\
\hline AKE TEST & $119.8 \pm 3.3$ & $\begin{array}{l}120.3 \pm 3 . \\
1\end{array}$ & $132.5 \pm 3.8$ & $\begin{array}{l}132.9 \pm 3 . \\
90\end{array}$ & -4.5 & -4.52 & 0.001 & 0.001 & SIGNIFICANT \\
\hline BSSRT & $11.9 \pm 4.0$ & $12.2 \pm 3.9$ & $22.8 \pm 4.61$ & $\begin{array}{l}23.0 \pm 4.2 \\
6 \\
\end{array}$ & -4.4 & -4.47 & 0.001 & 0.001 & SIGNIFICANT \\
\hline
\end{tabular}

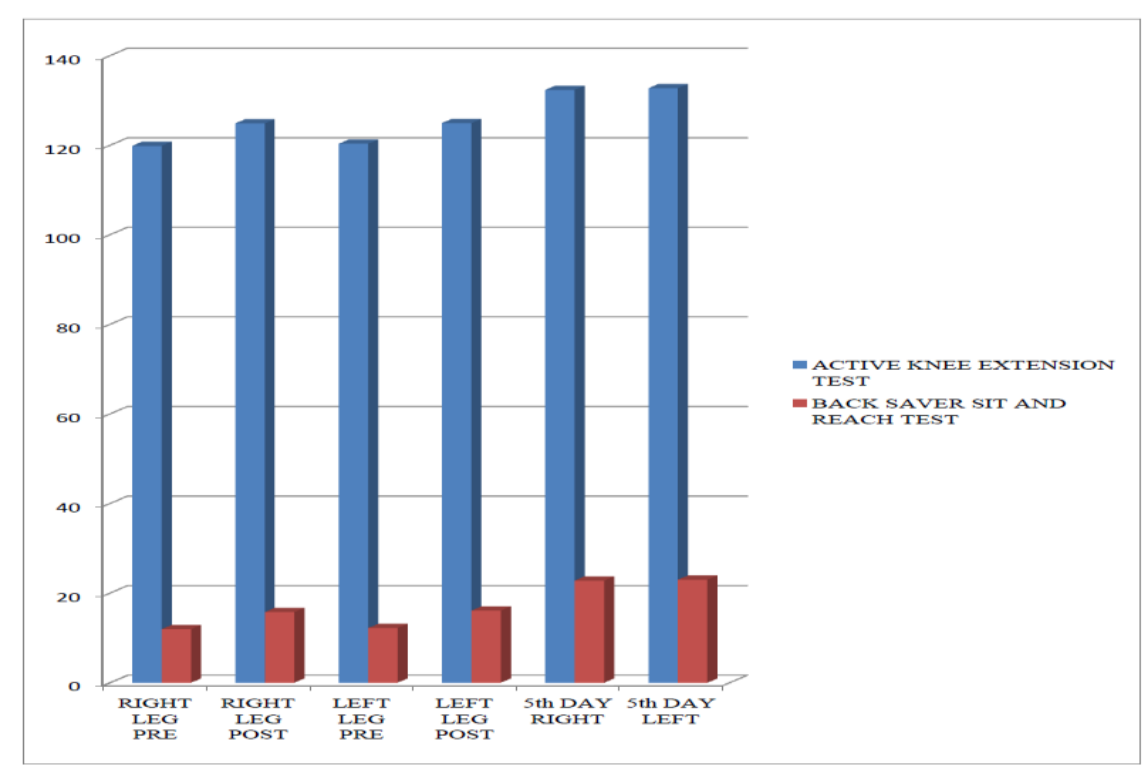

GRAPH 4: WITHIN GROUP COMPARISON OF GROUP B

TABLE 8: BETWEEN GROUP COMPARISON OF BOTH GROUPS Difference between pre test and post test (Immediate effect)

\begin{tabular}{|c|c|c|c|c|c|c|c|}
\hline \multirow{4}{*}{ OUTCOME MEASURES } & \multicolumn{7}{|c|}{ Difference between pre test and post test (Immediate effect) } \\
\hline & \multirow{2}{*}{\multicolumn{2}{|c|}{$\begin{array}{l}\text { SMIT } \\
\text { MEAN } \pm \text { SD }\end{array}$}} & \multirow{2}{*}{\multicolumn{2}{|c|}{$\begin{array}{l}\text { MET } \\
\text { MEAN } \pm \text { SD }\end{array}$}} & \multirow{2}{*}{\multicolumn{2}{|c|}{ SIGNIFICANCE }} & \multirow{3}{*}{ REMARKS } \\
\hline & & & & & & & \\
\hline & RT LEG & LT LEG & RT LEG & LT LEG & $\begin{array}{l}\text { RT } \\
\text { LEG }\end{array}$ & $\begin{array}{l}\text { LT } \\
\text { LEG }\end{array}$ & \\
\hline AKE TEST & $5.03 \pm 2.04$ & $5.26 \pm 1.99$ & $5.76 \pm 1.24$ & $5.65 \pm 1.01$ & 0.64 & 0.28 & $\begin{array}{l}\text { NOT } \\
\text { SIGNIFICANT }\end{array}$ \\
\hline BSSRT TEST & $3.61 \pm 1.20$ & $3.63 \pm 0.39$ & $3.82 \pm 0.90$ & $3.88 \pm 0.82$ & 0.64 & 0.33 & $\begin{array}{l}\text { NOT } \\
\text { SIGNIFICANT }\end{array}$ \\
\hline
\end{tabular}

TABLE 9: BETWEEN GROUP COMPARISON OF BOTH GROUPS

\begin{tabular}{|c|c|c|c|c|c|c|c|}
\hline \multirow{4}{*}{ OUTCOME MEASURES } & \multicolumn{6}{|c|}{ GICINICA } & \multirow{4}{*}{ REMARKS } \\
\hline & SMIT & & MET & & \multirow{2}{*}{\multicolumn{2}{|c|}{ SIGNIFICANCE }} & \\
\hline & \multicolumn{2}{|c|}{ MEAN \pm SD } & \multicolumn{2}{|l|}{ MEAN \pm SD } & & & \\
\hline & RT LEG & LT LEG & RT LEG & LT LEG & $\begin{array}{l}\text { RT } \\
\text { LEG }\end{array}$ & $\begin{array}{l}\text { LT } \\
\text { LEG }\end{array}$ & \\
\hline AKE & $9.69 \pm 2.72$ & $9.61 \pm 2.46$ & $12.61 \pm 3.2$ & $12.61 \pm 3.04$ & 0.001 & 0.000 & SIGNIFICANT \\
\hline BSSRT & $9.53 \pm 1.42$ & $9.42 \pm 1.42$ & $10.88 \pm 2.04$ & $10.84 \pm 2.03$ & 0.008 & 0.013 & SIGNIFICANT \\
\hline
\end{tabular}

\section{AKE TEST- ACTIVE KNEE EXTENSION TEST BSSRT- BACK SAVER SIT AND REACH TEST}

Table 8 and 9 shows between group comparisons. Mann Whitney $\mathrm{U}$ test was used for between group analysis. Here the difference of pre test and Post test
(Immediate effect) was taken and between group comparison of AKE and BSSRT shows statistically non significant difference i.e. Immediate effect of both the techniques were equally effective as shown in graph 5 but when the difference of pretest and at the end of $5^{\text {th }}$ session of both the groups were 
taken and between group comparison of AKE and back saver sit and reach test shows statistically significant difference $(\mathrm{p}<0.05)$. Hence control group Group-B shows more improvement in flexibility as compared to Group A as shown in graph 6.

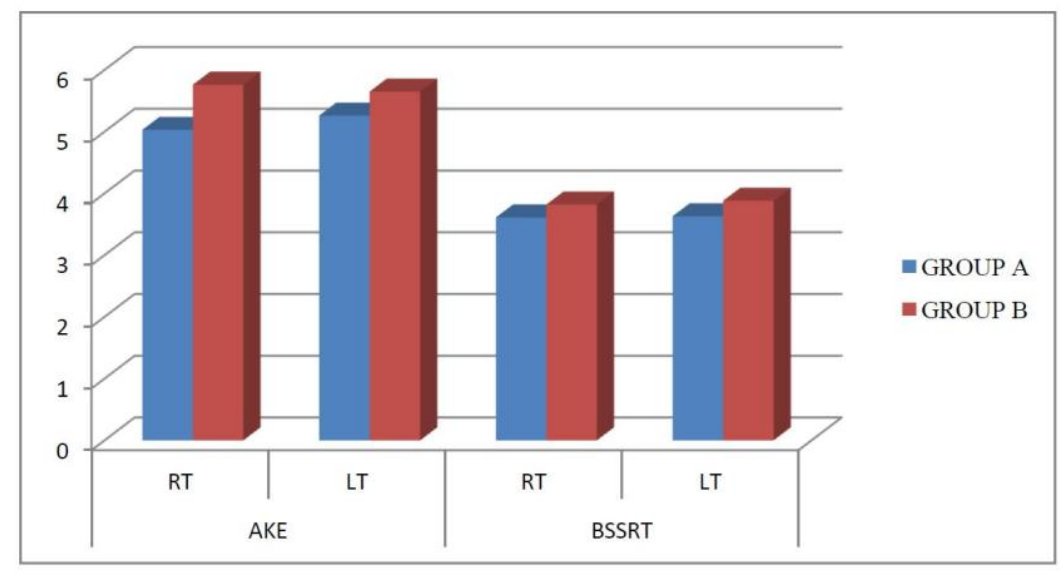

GRAPH 5: MEAN DIFFERENCE BETWEEN 2 GROUPS (Pre vs Post

Treatment (Immediate effect)

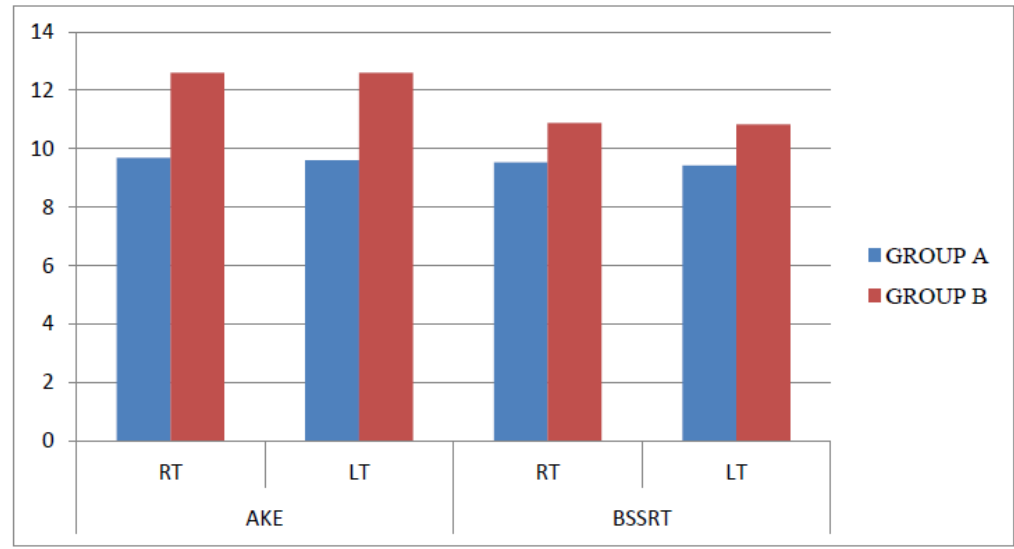

GRAPH 6: MEAN DIFFERENCE BETWEEN 2 GROUPS (Pre vs At the

End of $5^{\text {th }}$ Session)

\section{DISCUSSION}

Optimal hamstring flexibility is vital for smooth movements of the spine and lower limbs, reduced flexibility can impose abnormal loading on the musculoskeletal system. $^{64}$

Various stretching techniques like PNF stretching, self- stretching, ballistic stretching and static stretching to increase the length of hamstrings has been described in the literature. ${ }^{16}$

The purpose of this study was to compare the effectiveness of suboccipital muscle inhibition technique versus muscle energy technique on hamstring flexibility in college going students amongst asymptomatic young individuals.

This study was conducted on 52 subjects (26 in each group). Out of total participants $15 \%$ were males and $85 \%$ were females in Group A whereas 38\% were males and $62 \%$ were females in Group B with an age group of 18-25 years and were selected according to inclusion criteria and subjects were randomly divided into 2 groups. Baseline measurements of active knee extension test and back saver sit and reach test score were taken on day ${ }^{1}$. 
Subjects of group A were treated with suboccipital muscle inhibition technique; Group B were treated with Muscle energy technique. Post data (Immediate effect) was collected after post treatment of $1^{\text {st }}$ day and at the end of $5^{\text {th }}$ session. The results obtained a marked improvement in Active knee extension test and back saver sit and reach test on both right and left side, after the treatment of $5^{\text {th }}$ session. Mean age in Group A and Group B was 21.73 and 22.46 years respectively. Mean BMI in Group A and Group B was 21.25 and 21.7 respectively.

The First objective of this study was to study the effect of Suboccipital Muscle Inhibition Technique on Active knee extension test and Back saver sit and reach test for Hamstring Flexibility. Treating the hamstring muscles in patients with acute lower back pain for increasing hamstring length such as local site stretching techniques may cause aggravation of the local inflammatory response and may cause further muscle spasm and guarding. ${ }^{55}$ Polland and Ward ${ }^{65}$ suggested a different approach i.e. cervical spine treatment that might avoid compressing or stretching irritable structures but still produce an increase in hip flexion range of motion and hamstring extensibility. ${ }^{65}$ Polland and Ward reported change in the extensibility of hamstring muscle following application of cervical isometrics contract and relax technique. They found significant increase in remote hip flexion range of motion. ${ }^{65}$

According to our study the Mean Baseline value for Flexibility that is active knee extension and back saver sit and reach test in Group A (Suboccipital Muscle Inhibition Technique) was 119.96 and 12.15 for right leg and120.5 and 12.71 for left leg and immediately after intervention the mean value of flexibility among participants in group A was 125.0 and 15.76 for right leg and 125.84 and 16.34 for left leg and at the end of $5^{\text {th }}$ session mean value was 129.3 and 21.50 for right leg and 130.3 and 22.1 for left leg.
The second objective of this study was to study the effectiveness of Muscle energy technique on Active knee extension test and Back saver sit and reach test for hamstring flexibility. Muscle Energy Technique (MET) is a manual therapy technique $^{22}$ which targets the soft tissues primarily and can be called as active muscular relaxation technique. ${ }^{60}$ It is a direct active post facilitating technique also known as post- isometric relaxation techniquePIRT which follow different principles individually. It is a procedure in which controlled, voluntary isometric contractions of a target muscle group are widely advocated. It is effective for lengthening of shortened muscle, strengthening the muscle as a lymphatic or venous pump to help drainage of fluids and for increasing range of motion (ROM). After muscle energy technique (MET) there is viscoelastic change in muscle which helps in increasing muscle flexibility. ${ }^{22}$

According to our study the Mean Baseline value for Flexibility that is active knee extension and back saver sit and reach test in Group B (Muscle Energy Technique) was 119.88 and 11.96 for right leg and 120.34 and 12.21 for left leg and immediately after intervention the mean value of flexibility among participants of Group B was 124.84 and 15.78 for right leg and 124.9 and 16.09 for left leg and at the end of $5^{\text {th }}$ session mean value was 132.5 and 22.8 for right leg and 132.9 and 23.0 for left leg.

The third objective of this study was to study the effectiveness of Suboccipital muscle Inhibition Technique Versus Muscle Energy Technique on Active Knee Extension Test and Back Saver Sit and Reach Test for hamstring flexibility. When comparison was done between the groups the difference of Mean baseline value of Active knee Extension Test was9.69 and 9.61 for Group A and 12.61 and 12.61 for Group B for Right and Left legs respectively and Back saver sit and Reach test was 9.53 and 9.42 for Group $\mathrm{A}$ and 
10.88 and 10.84 for Group B for Right and Left Legs respectively.

In this study Both the treatment groups showed statistically significant improvement in flexibility but, pre test and post test (Immediate effect) when compared between both the groups was found to be non significant which supports null hypothesis whereas comparison of pre test and post test $\left(5^{\text {th }}\right.$ day) values of the active knee extension test and back saver sit and reach test between the groups showed statistically significant improvement in group B (Muscle energy technique) for improving flexibility which accepts the alternate hypothesis.

The present study showed that the improvement in hamstring flexibility in suboccipital muscle inhibition technique group was less than that of muscle energy technique group. Some authors concluded that 30 seconds optimal duration for an effective stretch in MET protocol which can maintain muscle elongation for the same duration leads to increase in muscle length. ${ }^{24}$ Another possible explanation for the improved flexibility could be because of viscoelastic nature of the muscle. ${ }^{25,54} \mathrm{Knott}$ and Voss proposed that the golgi tendon organ is a nerve receptor found in tendons that fires when tension increases in the tendon. This tension can be due to stretch or contracting muscle. When the golgi tendon organ fires a signal is sent to the spinal cord causing the agonist muscle to relax. ${ }^{66,54}$

Pramod K. Jagtap et al, 2015 studied the effect of Suboccipital Muscle Inhibition Technique on hamstring tightness patients. It was concluded that Suboccipital Muscle inhibition technique is effective in improving the flexibility of hamstring muscle. ${ }^{55}$

Dr RasikaPanse et al, 2018 studied the effect of Suboccipital Muscle Inhibition and Neural Flossing Techniques on Hamstring Flexibility in Young Adults. It was concluded that Hamstring tightness and stretch pain reduced significantly when combination of suboccipital muscle inhibition and neural flossing technique was given in young adults. ${ }^{56}$

The present study along with the other studies ${ }^{55}$ suggested new approach to the treatment of impaired hamstring extensibility and encouraged further investigation of remote effect of cervical treatment favouring the authors who concluded that manual therapy of neck may have a role to play in treatment of extra spinal lower limb musculoskeletal conditions. ${ }^{55}$

Waseem $\mathrm{M}$ et $\mathrm{al}^{60}$ concluded that MET significantly improved hamstring flexibility in collegiate males. MET increased muscle length by a combination of creep and plastic changes in connective tissue. $^{24,} 32$ It occurred due to biomechanical or neuro-physiological changes or due to an increase in tolerance to stretching. ${ }^{29}$ Neurophysiological and biomechanical mechanism may underlie changes to both ROM and muscle stiffness following the application of MET. The neuro physiological component is explained by inhibition of motor activity of muscle exposed to stretch, the objective of stretching is therefore to minimize muscle activity to reduce resistance to stretching. ${ }^{67}$

Sejal Sailor et al, 2018 studied the comparative effect of muscle energy technique and positional release technique on hamstring flexibility in healthy individuals. It was concluded that MET is more effective than positional release technique (PRT) for healthy individuals with normal and limited hamstring flexibility. ${ }^{61}$

According to Dr. Ujwal L et al, 2017 studied the effect of Muscle energy technique versus Effect of neural Tissue mobilization on Hamstring tightness in young adults. It concluded that Muscle energy technique is more effective than Neural Tissue Mobilization for improving hamstring flexibility in young adults. ${ }^{62}$

This study showed significant effect in Suboccipital muscle inhibition technique and Muscle energy technique on hamstring flexibility. Thus, both can be further 
implemented in clinical practice to treat the hamstring tightness according to the availability of the clinical set up and the trained physiotherapists.

\section{LIMITATIONS}

1) Gender distribution was unequal.

2) Study was done only in age group of 1826 years.

3) Blinding was not done.

4) Long term follow up was not taken.

\section{FUTURE RECOMMENDATIONS}

1) Future studies are needed to examine effectiveness of Sub Occipital Muscle Inhibition technique and Muscle Energy Technique on hamstring flexibility on Mechanical/Non Specific Low Back Pain.

2) Studies can be carrried to examine Immediate Effect as well as Long Term Effect of SMI technique in comparison with other flexibility techniques

3) More studies can be done on sports specific population.

\section{CONCLUSION}

This study shows that Suboccipital Muscle Inhibition Technique and Muscle Energy Technique both the treatment techniques were effective in improving hamstring flexibility but Muscle energy technique was found to be more effective in improving hamstring flexibility. So, both the techniques can be further recommended to treat hamstring tightness.

\section{ACKNOWLEDGEMENT}

I would like to thank the patients who were a part of my study.

\section{Conflict of Interest: None}

\section{Source of Funding: None}

\section{REFERENCES}

1. Deborah Turner starring, Marilyn R. Gossman, Garvice G. Nicholson, Jr, Jack Lemons. Comparison of cyclic and sustained passive stretching using a mechanical device to increase resting length of hamstring muscles. American Physical Therapy Association members. 1998 March; 68(3):314-320.

2. Madeleine Smith, B. Clin. Sc., M.H. Sc. (Osteo), Gary fryer, PhD, B. App.Sc. (Osteo), N.D. A Comparison of two muscle energy techniques for increasing flexibility of the hamstring muscle group. Journal of body work and movement therapies. 2008 June; 12:312-317.

3. S. Sharon Wang, MS, PT, Susan L. Whitney, PhD, PT, ATC, Ray G. Burdett, $\mathrm{PhD}$, PT, Janine E. Janosky, PhD. Lower Extremity muscular Flexibility in long distance Runners. Journal of Orthopaedic and Sports Physical therapy.1993 February; 17(2):102-7.

4. Glen M. Depino, Med, ATC, William G. Webright, Med, ATC, PT, Brent L. Arnold, $\mathrm{PhD}$, ATC. Duration of maintained Hamstring flexibility after cessation of an acute static stretching protocol. Journal of Athletic Training. 2000 January-March; 35(1):56-59.

5. Kieran O' Sullivan, Elaine Murray, David Sainsbury. The effect warm up, Static stretching and dynamic stretching on hamstring flexibility in previously injured subjects. BMC musculoskeletal Disorders. 2009 April; 16:10-37 .

6. Bhagyashree K. Koli, Deepak B. Anap. Prevalence and severity of hamstring tightness among college student: A cross sectional Study. International Journal of Clinical and biomedical Research. 2018; 4(2): 65-68.

7. Houston MN, HodsonVE, Adams KK, Hoch JM. The effectiveness of whole- body vibration training in improving hamstring flexibility in physically active adults. Journal of sports rehabilitation. 2015 February; 24(1): 77-82.

8. Shah Vidhi, Thakur Anuprita, Karajgi Asmita, Dabholkar Twinkle, Pandit Unnati, Yardi Sujata. Comparsion of PNF technique with NDS technique for hamstrings tightness in asymptomatic subjects. Indian Journal of physiotherapy and occupational therapy.2014; 8(3): 158-161.

9. Wendell Liemohn, BA, MS, PhD, Larry B. Snodgrass, BS, PT, Gina L. Sharpe, BS, MS. Unresolved controversies in back management- A Review. The Journal of 
Orthopaedic and sports physical therapy. 1998 January; 9(7):239-244.

10. Christine E. Saudek, MS, PT, Karen A. Palmer, MS, PT. Back pain Revisited. The journal of orthopaedic and sports physical therapy. 1987 June; 8(12):556-566.

11. Walter Alston M.D, Karl E. Carlson M.D, Daniel J. Feldman M.D, Zane Grimm M.S, EvangeloGerontinos M.S. A Quantitative study of muscle factors in the chronic low back syndrome. Journal of the American Geriatrics Society. 1966 October 14

12. Mellin, G. Correlations of hip mobility with degree of back pain and lumbar spinal mobility in chronic low back pain patients. Spine. 1988 June; 13:668-670.

13. Nagarwal A.K., Zutshi, Ram C.S., Zafar R. Improvement of hamstring Flexibility: A comparison between two PNF Stretching Techniques. International Journal of sports Science and engineering. 2009 September; 04(01):25-33.

14. A.P. Margues, A.A.P. Vasconcelos, C.M.N. Labral, I.C.N. Sacco. Effect of frequency of static stretching on flexibility, hamstring tightness and electromyographic activity. Brazilian Journal of Medical and Biological Research. 2009 October; 42(10): 949- 953.

15. AbdulrahimZakaria, GaneswaraRao, Melam, CyamalaBuragadda. Efficacy of PNF stretching Techniques on hamstring tightness in Young Male Adult Population. World Journal of Medical Sciences.2012; 7(1):23-26.

16. D. Scott Davis, Paul E. Ashby, Kristi L. McCale, Jerry A. McQuain, Jaime M. Wine. The Effectiveness of 3 stretching techniques on hamstring flexibility using consistent stretching parameters. Journal of strength and conditioning Research. 2005; 19(1): 2732.

17. NilosMalliaropoulos, JurdanMendiquchia, Hercules Pehlivanidis, Sofia Papadopoulous, Xavier Valle, Peter Malliaras, et al. Hamstring Exercises for track and field athletes: Injury and exercise biomechanics and possible implications for exercise selection and primary prevention. British Journal of Sports Medicine. 2011; 46(12).

18. R C Hallgren, PE Greenman, J JRechtien.Atrophy of suboccipital muscles in patients with chronic pain: a pilot study. The journal of American osteopathic Association. 1994; 94(12): 1032-1038.
19. John M McPartland, Raymond R. Brodeur, Richard C. Hallgren. Chronic neck pain, standing balance and suboccipital muscle atrophy: a pilot study. Journal of manipulative and physiological therapeutics.1997; 20(1):24-29.

20. Erika Quintana Aparicio, Luis BorralloQuinante, cleofas Rodriquez Blanco, FrancisioAlburquerqueSendin. Immediate effect of suboccipital muscle inhibition technique in subjects with short hamstring syndrome. Journal of manipulative and physiological therapeutics. 2009; 32(4): 262-269.

21. Gary D. Hack, Richard T. Koritzer, Walker L. Robinson, Richard C. Hallgren, Philip E Greenman. Anatomic Relation Between the rectus Capitis Posterior Minor muscle and the duramater. Spine. 1995; 20(23): 24842486.

22. Ballantyne F, Fryer G, McLaughlin P. The effect of muscle energy technique on hamstring extensibility: the mechanism of altered flexibility. Journal of Osteopathic medicine. 2003; 6(2): 59-63.

23. Norkin C. C. Measurement of joint motion: A Guide of goniometry, $2^{\text {nd }}$ edition page 142-144.

24. Fryer G. Muscle Energy Concepts- a need for change. Journal of Osteopathic Medicine. 2000; 3(2): 309-9.

25. Taylor DC, Dalton JD, Seaber AV, Garrett WE. Viscoelastic properties of muscle tendon units. The American Journal of Sports Medicine. SAGE Publications; 1990 May; 29-38.

26. Hutton RS. Neuromuscular Basis of Stretching Exercises In: Komi PV. Strength and Power in Sport.1992: 29-38.

27. Baltaci G, Un N, Tunay V, Besler A, Gerceker S. Comparison of three different sit and reach tests for measuring of hamstring flexibility in female university students. Br journal of sports medicine. 2003 February; 37(1): 59-61.

28. Booher James M, Thibodeau, Gary A. Athletic Injury Assessment. McGraw-Hill. $4^{\text {th }}$ edition.

29. Richard Gajdosik, Gary Lusin. Hamstring muscle tightness Reliability of Active Knee extension Test. 1983, July; 63(7): 10851088.

30. Malanga GA, K Mautner. Musculoskeletal Physical Examination: An Evidence based approach. Elsevier Health sciences 2016 
31. Bohannon RW. Cinematographic analysis of the passive straight-leg- raising test for hamstring muscle length. Journal of physical therapy. 1982, September; 62(9): 1269- 1274.

32. Ross A Clark. Hamstring Injuries: Risk Assessment and Injury Prevention. Annals of academy of medicine. 2008, May; 37(4):341-346.

33. Kuilart, KE, Woollam M, Barling E, Lucas N.P. The active knee extension test and slump test in subjects with perceived hamstring tightness. International journal of osteopathic medicine. 2005, September; 8(3): 89-97.

34. Patterson P, Wiksten DL, Ray L, Flanders C, Sanphy D. The validity and reliability of the back saver sit- and - reach test in middle school girls and boys. Research Quarterly for Exercise and Sport.1996, December; 67(4): 448-451.

35. Liemohn WP, Sharpe GL, Wasserman JF. Lumbosacral movement in the sit-and reach and in cailliet's protective- hamstring stretch. Spine. 1994, September; 19(18): 2127-2130.

36. C. Askling, J. Karlsson, A. Thorstensson. Hamstring injury occurance in elite soccer players after preseason strength training with eccentric overload. Scandinavian Journal of Medicine and Science in Sports. 2002 December; 13: 244-250.

37. Kevin M. Cross, Kelly K Gorke, Mark Conaway, Christopher D. Ingersoll. Hamstring strain incidences between genders and sports in NCAA athletics. Athletic training and Sports health care. 2010; 2(3): 124-130.

38. Engebretsen, A.H, Myklebust, G, Holme, I, Engebretesen , L, Bahr, R. Intrinsic risk factors for hamstring injuries among male soccer players. American Journal of Sports Medicine. 2010; 38: 1147-1153.

39. Pedro A. Lopez- Minarro, PilarSainz de BarandaAndujar, Pedro L. Rodriguez Garcia. A comparison of the sit and reach test and the back- saver sit- and -reach test in university students. Journal of sports science and medicine. 2009; 8: 116-122.

40. B D Chaurasia's. Human Anatomy. CBS. $5^{\text {th }}$ edition.

41. Gmch.gov.in/estudy/e\%20lectures/Anatomy/Back\%20of\% 20thigh.pdf
42. Post thigh at The Anatomy Lesson by Wesley Norman (Georgetown University).

43. Ishanka Weerasekara, IreshaKumari, Nilushika Weerarathna, CharithWithanage, Chamika Wanniarachchi, Yancy Mariyanayagam. Prevalence of Hamstring Tightness among the Male Athletes of University of Peradeniya. International Journal of Physical Medicine \& Rehabilitation, 2013,1:108.

44. Nishikawa Y, Aizawa J, Kanemura N, Takahashi T, Hosomi N, Maruyama $\mathrm{H}$. Immediate effect of passive and active stretching on hamstring flexibility: A single blinded randomized control trial. Journal of physical therapy sciences.2015, Oct; 27(10): 3167-3170.

45. Kyoung-IL Lim, Hyung-Chun Nam, Kyoung-Sim Jung. Effects on hamstring Muscle Extensibility, Muscle Activity, and Balance of Different Stretching Techniques. Journal of Physical Therapy. 2014, February; 26(2):209-213.

46. Felipe Jose Jandre Reis, Adriana RibeiroMacedo. Influence of Hamstring Tightness in Pelvic, Lumbar and Trunk Range of Motion in Low Back Pain and Asymptomatic Volunteers during Forward Bending. Asian Spine J. 2015, Aug; 9(4): 535-540.

47. Divan MohaideenAbbas,Bilques Sultana. Efficacy of active stretching in improving the hamstring flexibility. International Journal of Physiotherapy and Research. 2014, Vol 2(5):725-32.

48. Carolyn Kisner, Lynn Allen colby. Therapeutic Exercises. Jaypee publications. $6^{\text {th }}$ edition.Jaypee publications. Medical publishers. Chapter 4. Stretching for impaired mobility: 72-118.

49. Myosportstherapy.co.uk/articles/2013/june/ Treating_Tight_Hamstrings.pdf

50. RadhikaTalapalli, MeghaSandeepSheth. Comparison of Muscle Energy technique and Post Isometric Relaxation on Hamstring Flexibility in Healthy Young Individuals with Hamstring Tightness. International Journal of Health and Rehabilitation Services. 2014 June; 3(2): 65-68.

51. McPartland JM, Brodeur RR: Rectus capitis posterior minor: a small but important suboccipital muscle. J BodywMovTher, 1999; 3: 30-35 
52. Ahmed M. Azam. Efficacy of sub-occipital muscles decompression techniques in restoringfunctional walking capacity in hemiplegic cerebral palsy children,International Journal of Contemporary PediatricsAzam AM. Int J ContempPediatr. 2017 Jul; 4(4):1132-1137

53. Sung- Hak Cho, PhD, PT, Soo- Han Kim, PhD, PT, Du-Jin Park, PhD, PT. The Comparison of the immediate effects of application of the suboccipital muscle inhibition and self myofascial release techniques in the suboccipital region on short hamstring. Journal of Physical Therapy Science. 2015 January; 27(1): 195197.

54. Chaitow, Leon, Muscle Energy Techniques, Third Edition. Churchill Livingstone, Edinburg, 2006.Chapter 1. An introduction to muscle energy techniques: 1-21, 82- 157.

55. Pramod K. Jagtap,Shubhangi D. Mandale. The effect of Suboccipital Muscle Inhibition Technique on Hamstring Tightness patients. Journal of Evolution of Medical and Dental Sciences. 2015 April 23; 4(33): 5682-5689.

56. Dr RasikaPanse, Dr UjwalYeole, ShubhadaTrivedi, Dr PournimaPawar. To study the Effect of Suboccipital Muscle Inhibition and Neural Flossing Techniques on Hamstring Flexibility in Young Adults. Journal of Medical Science and Clinical Research. 2018 November; 6(11): 846

57. M. Ramesh, P. Sivasankar. Comparison of three different physiotherapeutic interventions in improving hamstring flexibility in individuals with hamstring tightness. International Journal of Health Sciences and Research. 2014 June; 4(6).

58. AzadehShadmehr,Mohmmad Reza Hadian, Sedigheh Sadat Naiemi,ShohrehJalaei. Hamstring flexibility in young women following passive stretch and muscle energy technique. Journal of back and Musculoskeletal Rehabilitation.2009 January: 143- 148.

59. Pratik Vakhariya, ShrutiPanchal, Bhumi Patel. Effects of Various therapeutic techniques in subjects with short hamstring syndrome. International Journal of Physiotherapy and Research. 2016; 4(4): 1603-10.
60. Mohd. Waseem, ShibiliNuhmani, C.S. Ram. Efficacy of Muscle Energy Technique on hamstring muscle flexibility in normal Indian collegiate males. Calicut Medical Journal. 2009, January; (7):e4.

61. Sejal Sailor, Yesha Mehta, Neha Shah, AnujaTrivedi. A comparative study of Muscle energy technique and positional release technique on hamstring flexibility in healthy individuals. Journal of integrated Health Sciences. 2018; 6(2): 64-68.

62. Dr Ujwal L, Yeole, Raaequa, M. Awati, Dr.Pournima, A. Pawar. Effect of Muscle energy technique vs Effect of Neural tissue Mobilization on hamstring tightness in young adults. International Journal of Current Research. 2017, December; 9(12): 62816-62819.

63. MohamadShariff A Hamid, Mohamed Razif Mohamed Ali, Ashril. Interrater and Intrarater Reliability of the Active knee Extension (AKE) test among Healthy Adults. Journal of Physical Therapy Science, 2013, Augest; 25(8): 957-961.

64. Andrew Wilson. Effective Management of Musculoskeletal Injury. A clinical Ergonomics Approach to prevention, Treatment and Rehabilitation. Journal of Hand therapy. 2004, March; 17(1): 72.

65. Pollard H, Ward G. The effect of Upper cervical or sacroiliac manipulation on hip flexion range of motion. Journal of manipulative physiotherapy. 1998, November december; 21(9): 611-616.

66. Knott M, Voss D.E. (1956) Proprioceptive neuromuscular facilitation: Patterns and techniques. New York.

67. Magnusson SP, Simonsen EB, Aagaard P, Dyhre- PoulsenP,McHugh MP, Kjaer M. Mechanical and physical responses to stretching with and without preisometric contraction inhuman skeletal muscle. Arch Phys Med Rehabilitation. 1996, April; 77(4): 373-8.

How to cite this article: Vachhani R, Sharma H. Effectiveness of suboccipital muscle inhibition technique versus muscle energy technique on hamstring muscle flexibility in college going students. International Journal of Research and Review. 2021; 8(6): 160-174. DOI: https://doi. org/10.52403/ijrr.20210620 